\title{
HUBUNGAN ANTARA PENGETAHUAN DAN SIKAP KELUARGA DENGAN TINGKAT KECACATAN PADA PENDERITA KUSTA DI RUMAH SAKIT UMUM DAERAH DR. SAIFUL ANWAR MALANG
}

\author{
Dhelya Widasmara*, Iriana Maharani**, Nanin Aprilia**®
}

\begin{abstract}
Abstrak
Perawatan dan dukungan untuk menurunkan tingkat kecacatan pada penderita kusta memerlukan partisipasi anggota keluarga. Keluarga yang memiliki pengetahuan baik dan sikap yang tepat mengenai penyakit kusta dapat menurunkan tingkat kecacatan pada penderita kusta. Kota Malang masih menjadi penyumbang jumlah penderita kusta di Jawa Timur dengan jumlah penderita kusta tertinggi di Indonesia. Tujuan penelitian ini adalah untuk mengetahui hubungan antara pengetahuan dan sikap keluarga dengan tingkat kecacatan penderita kusta di Rumah Sakit Umum Daerah Dr. Saiful Anwar Malang pada bulan Mei sampai Juli tahun 2017. Tingkat kecacatan diukur menggunakan kriteria WHO yaitu grade 0, grade 1,dan grade 2. Pengetahuan dan sikap keluarga diukur menggunakan kuesioner yang diberikan bersamaan dengan observasi tingkat kecacatan. Penelitian dilaksanakan di wilayah kerja RS. Dr. Saiful Anwar dengan metode cross sectional. Jumlah subjek penelitian adalah 19 orang dengan teknik total sampling. Analisis data pada penelitian ini menggunakan uji chi-square. Hasil penelitian menunjukkan bahwa pengetahuan dan sikap keluarga memiliki hubungan yang signifikan dengan tingkat kecacatan penderita kusta di RS. Dr. Saiful Anwar Malang (masing-masing $p=0,010, O R=8,1$ dan $p=0,017, O R=7,3$ ). Dapat disimpulkan bahwa terdapat hubungan yang bermakna antara pengetahuan dan sikap keluarga dengan tingkat kecacatan pada penderita kusta di RS. Dr. Saiful Anwar Malang.
\end{abstract}

Kata kunci: kusta, pengetahuan, sikap, tingkat kecacatan.

\section{THE FAMILY'S KNOWLEDGE AND ATTITUDE WITH THE LEVEL OF PATIENTS DISABILITY AT DR. SAIFUL ANWAR GENERAL HOSPITAL MALANG}

\begin{abstract}
Caring and supporting in reducing the level of disability of leprosy patients need the participation of family members. The family who have a good knowledge and a good attitude towards leprosy could reduce the level of disability of the leprosy patients. Malang is still being the contributor to the number of leprosy patients in East Java, in which East Java has the highest number of leprosy patients in Indonesia. The purpose of this research to determine the family's knowledge and attitude with the level of leprosy patients at Dr. Saiful Anwar hospital in Malang during May until July 2017. The disability were measured using WHO criteria: grade 0 , grade 1 , and grade 2 . Meanwhile, the family's knowledge and attitude were measured using a questionnaire given the disability level observation. The research was held in Dr. Saiful Anwar Hospital using cross sectional. The number of research subject was 19 people using the total sampling technique. The chi-square test showed that the family's knowledge and attitude have the significant relationship with the disability level of leprosy patients in Dr. Saiful Anwar Hospital $(p=0.010, O R=8.1$ and $p=0.017, O R=$ 7.3 , respectively). It can be concluded that knowledge and attitude of the family related to the disability level of leprosy patients at Dr. Saiful Anwar Hospital Malang.
\end{abstract}

Keywords: attitude,knowledge, leprosy, level of disability.

* Departemen IImu Kesehatan Kulit dan Kelamin, Fakultas Kedokteran, Universitas Brawijaya

** Departemen Ilmu Kesehatan Telinga Hidung Tenggorokan-Kepala Leher, Fakultas Kedokteran,

Universitas Brawijaya

${ }^{* * *}$ Program Studi Sarjana Kedokteran (S1), Fakultas Kedokteran, Universitas Brawijaya

E-mail: naninap3@gmail.com 


\section{Pendahuluan}

Penyakit kusta merupakan penyakit infeksi kronis pada manusia yang disebabkan oleh bakteri Mycobacterium leprae. Kusta dapat menyebabkan kecacatan jika tidak didiagnosis dan diberi pengobatan sedini mungkin. ${ }^{1}$ Penyakit ini dapat menyerang kulit, saraf perifer, mukosa saluran pernapasan atas dan mata. ${ }^{2}$ Diagnosis penyakit kusta ditegakkan dengan ditemukannya tanda utama (cardinal sign) yaitu: 1).Kelainan lesi kulit berbentuk bercak putih (hipopigmentasi) atau kemerahan (eritema) yang mati rasa (anestesi), 2). Penebalan saraf tepi yang disertai dengan gangguan fungsi saraf, dan 3). Adanya basil tahan asam (BTA) pada kerokan jaringan kulit (slit skin smear). ${ }^{3}$ Kusta dapat disebut sebagai the great imitator dalam penyakit kulit. ${ }^{4}$

Menurut WHO, tahun 2015 total kasus baru yang tercatat di 108 negara adalah 211.973. Kasus tertinggi berturut-turut adalah India memiliki $60 \%$ dari kasus global, diikuti Brazil dan Indonesia. ${ }^{5,6}$ Kasus baru kusta pada tahun 2013 terbanyak di provinsi Jawa Timur dan Kota Malang merupakan salah satu penyumbang kusta di Jawa Timur tercatat tingkat prevalensi yaitu 0,25 per 10.000 penduduk. ${ }^{7}$

Tingkat kecacatan dibagi menjadi grade 0 , grade 1,dan grade 2.,9 Kecacatan merupakan istilah ilmiah yang menunjukkan penurunan atau abnormalitas dari struktur dan fungsi anatomi atau fisiologi. 8 International Classification of Function Disability and Health (ICF) menyebutkan kecacatan merupakan kerusakan struktur dan fungsi (impairment), keterbatasan aktifitas (activity limitation), dan masalah partisipasi (participation problem). Ketiga aspek ini sangat dipengaruhi oleh faktor individu dan faktor lingkungan. Keluarga merupakan salah satu faktor lingkungan yang berpengaruh terhadap kecacatan pada penderita kusta. ${ }^{9}$

Keluarga dapat memberikan perawatan dan dukungan pada anggota keluarga yang sakit dalam upaya menurunkan tingkat kecacatan penderita kusta Selain itu, keluarga dapat membuat keputusan tindakan kesehatan yang tepat. Peran keluarga diharapkan dapat meningkatkan perawatan bagi penderita kusta untuk meminimalkan terjadinya kecacatan dalam memenuhi kebutuhan sehari-hari. ${ }^{10}$ Pada negara berkembang, ketidak-tahuan (ignorancy) keluarga maupun masyarakat terhadap kusta masih memiliki pandangan yang negatif (stigma) berupa kepercayaan bahwa kusta merupakan suatu penyakit kutukan. ${ }^{11,12} \quad$ Keadaan tersebut menyebabkan penderita kusta mengalami perlakuan yang diskriminatif dan tidak mendapatkan pertolongan yang memadai. ${ }^{13}$

Penelitian Susanto dkk., di Yogyakarta pada tahun 2009 menunjukkan hubungan yang signifikan antara pengetahuan keluarga dengan tingkat kecacatan pada penderita kusta. Dari hasil penelitian tersebut diketahui bahwa sebagian besar keluarga dengan tingkat pengetahuan yang rendah terhadap kusta diakibatkan kurangnya peran petugas kesehatan terhadap pemberian informasi mengenai kusta. ${ }^{14}$ Penelitian di Kabupaten Padang Pariaman juga menunjukkan hubungan yang signifikan antara pengetahuan dan sikap keluarga dengan tingkat kecacatan pada penderita kusta. Berdasarkan penelitian tersebut diketahui bahwa sikap yang diskriminatif dan stigma yang salah terhadap kusta dapat meningkatkan tingkat kecacatan. ${ }^{15}$

Melihat pentingnya upaya pencegahan kecacatan penderita kusta melalui peran keluarga dalam merawat penderita kusta, maka masih diperlukan data yang lebih banyak sebagai dasar petugas kesehatan memberikan edukasi kepada masyarakat. Untuk itu, dilakukan penelitian mengenai 
hubungan antara pengetahuan dan sikap keluarga dengan tingkat kecacatan penderita kusta di RS. Dr. Saiful Anwar Malang.

\section{Bahan dan Metode}

Desain penelitian yang digunakan adalah observasional dengan pendekatan cross sectional. Penelitian dilakukan di RSUD Dr.Saiful Anwar Malang pada bulan Mei-Juli 2017. Adapun yang menjadi responden adalah keluarga pasien.

Variabel bebas pada penelitian ini adalah pengetahuan keluarga dan sikap keluarga, sedangkan variabel terikat yaitu tingkat kecacatan.

Alat ukur yang digunakan dalam penelitian ini adalah kuesioner untuk menilai pengetahuan dan sikap keluarga terhadap penyakit kusta. Penilaian tingkat kecacatan menggunakan checklist observasi berdasarkan WHO tahun 2016. ${ }^{16}$ Alat ukur yang digunakan untuk menilai pengetahuan dan sikap keluarga adalah kuisioner yang dimodifikasi dari penelitian Susanto tahun 2012. Berdasarkan Pedoman Nasional Program Pengendalian Penyakit Kusta menurut Kementerian Kesehatan RI tahun 2012 dan WHO tentang Upaya Pencegahan Kecacatan pada Penderita Kusta. 4,17

Uji validitas dan reliabilitas dilakukan pada bulan April dengan sampel sebanyak 10 orang sesuai dengan kriteria inklusi. Dari hasil analisis diperoleh bahwa 15 pertanyaan dari 19 pertanyaan dapat digunakan sebagai butir soal tentang pengetahuan keluarga terhadap penyakit kusta. Sementara itu, untuk butir soal sikap keluarga terhadap penyakit kusta didapatkan 12 pertanyaan yang dapat digunakan dari 15 pertanyaan yang disediakan.

Dengan demikian, untuk pengukuran pengetahuan keluarga maka kuisioner pada penelitian ini menggunakan 15 pertanyaan. Kuisioner berupa pilihan ganda dan nilai tertinggi yang dicapai responden dari semua pertanyaan adalah 30. Agar didapatkan persentase untuk interpretasi hasil maka digunakan rumus sebagai berikut:

$$
\text { nilai }(\%)=\frac{\text { jumlah skor tiap responden }}{\text { jumlah skor maksimaI }} \times 100
$$

Untuk pengukuran sikap terdapat 12 pernyataan menggunakan skala Likert dengan kriteria: Sangat Setuju (SS), Setuju (S), Tidak setuju (TS), dan Sangat Tidak Setuju (STS). ${ }^{18}$ Untuk interpretasi hasil maka diperlukan rumus sebagai berikut:

$$
\text { nilai }(\%)=\frac{\text { jumlah skor tiap responden }}{\text { jumlah skor maksimaI }} \times 100
$$

Hasil

Pada penelitian ini, didapatkan 19 responden yang memenuhi kriteria inklusi dan bersedia mengikuti penelitian. Pada Tabel 1 ditunjukkan karakteristik responden (keluarga pasien), dengan responden terbanyak adalah perempuan. Umur responden dibagi menjadi tiga kelompok yaitu kelompok umur 25-40 tahun, 41-55 tahun, dan $\geq 56$ tahun. Kelompok terbanyak yaitu kelompok umur 25-40 tahun sebanyak 10 responden, kelompok umur 41-55 tahun sebanyak 8 responden, sementara distribusi terendah pada kelompok umur $\geq 56$ tahun yaitu sebanyak 1 responden.

Tingkat pendidikan terbanyak pada tingkat pendidikan tamat SMA diikuti SMP, perguruan tinggi, dan SD tamat maupun tidak. Pekerjaan responden beragam dengan yang terbanyak adalah ibu rumah tangga, kemudian buruh, tukang jahit dan petani, sedangkan paling sedikit yaitu pedagang. Mayoritas merupakan suami atau istri dari penderita kusta. Responden pada penelitian ini adalah anak, ayah/ibu, atau kakak/adik penderita kusta.

Berdasarkan hasil penelitian, didapatkan diistribusi frekuensi pengetahuan responden tentang penyakiit kusta yang ditampilkan pada Gambar 1. Hasil analisis univariat responden didapatkan bahwa dari 
19 responden yang memiliki pengetahuan baik sebanyak 12 orang $(63,2 \%)$ dan berpengetahuan kurang sebanyak 7 orang $(36,8 \%)$.

Berdasarkan hasil kuisioner mengenai pengetahuan terhadap kusta yang diisi oleh keluarga pasien menunjukkan masih terdapat beberapa jawaban yang salah yang diuraikan pada Tabel 2. Dari hasil kuisioner tersebut terbanyak jawaban salah pada pertanyaan mengenai penyebab dari kusta, dengan sebagian besar menjawab "tidak tahu".

Tabel 1. Distribusi karakteristik responden.

\begin{tabular}{lcc}
\hline Karakteristik Responden & Frekuensi & Persentase (\%) \\
\hline Jenis Kelamin & & \\
$\quad$ Laki-laki & 8 & 42 \\
$\quad$ Perempuan & 11 & 58 \\
\hline Usia & & \\
$25-40$ & 10 & 53 \\
$41-55$ & 8 & 42 \\
$\quad>55$ & 1 & 5 \\
\hline Pendidikan & & \\
SD & 2 & 11 \\
Tamat SMP & 5 & 26 \\
Tamat SMA & 10 & 53 \\
Tamat PT & 2 & 11 \\
\hline Pekerjaan & & \\
IRT & 6 & 32 \\
Petani & 2 & 11 \\
Buruh & 3 & 16 \\
Karyawan & 5 & 26 \\
Pedagang & 1 & 5 \\
Penjahit & 2 & 11 \\
\hline Hubungan Keluarga & & \\
Ayah/ibu & 2 & 11 \\
Anak & 3 & 16 \\
Kakak/adik & 2 & 11 \\
Suami/istri & 12 & 63 \\
\hline
\end{tabular}

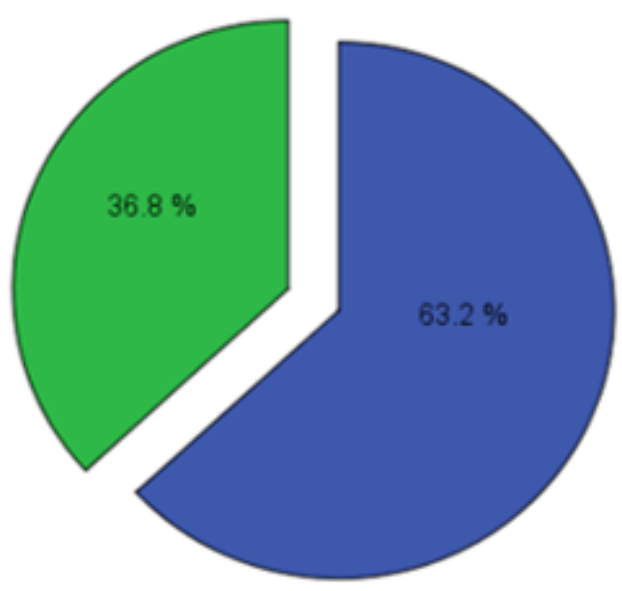

Buruk $\square$ Baik

Gambar 1. Distribusi tingkat pengetahuan responden mengenai kusta. 
Tabel 2. Rincian hasil kuisioner pengetahuan keluarga.

\begin{tabular}{lcc}
\hline \multicolumn{1}{c}{ Pertanyaan } & Jawaban Benar & Jawaban Salah \\
\hline Apa yang anda ketahui tentang kusta? & 16 & 3 \\
\hline Apa penyebab penyakit kusta? & 8 & 11 \\
\hline Apa yang anda ketahui tentang tanda-tanda penyakit kusta? & 12 & 7 \\
\hline Apakah penyakit kusta dapat menular? & 10 & 9 \\
\hline $\begin{array}{l}\text { Jika dapat menular, menurut anda bagaimana cara } \\
\text { penularannya? }\end{array}$ & 12 & 7 \\
\hline $\begin{array}{l}\text { Apakah anda tahu akibat yang ditimbulkan oleh penyakit } \\
\text { kusta? }\end{array}$ & 15 & 4 \\
\hline Apakah penyakit kusta dapat disembuhkan? & 16 & 3 \\
\hline Jika ya, berapa lama pengobatan kusta sampai sembuh? & 9 & 10 \\
\hline Apa akibat apabila tidak menyelesaikan pengobatan? & 14 & 5 \\
\hline Apakah anda tahu pengobatan kusta dengan MDT? & 15 & 4 \\
\hline Jika tahu, apa obat MDT tersebut? & 14 & 5 \\
\hline Kapan saja penderita kusta harus mengambil obat? & 14 & 5 \\
\hline Darimana penderita kusta mendapatkan obat selama ini? & 16 & 3 \\
\hline Dimana penderita kusta dapat berobat? & 13 & 6 \\
\hline Apakah kecacatan pada penyakit kusta dapat dicegah? & 12 & 7 \\
\hline
\end{tabular}

Berdasarkan hasil penelitian, didapatkan diistribusi frekuensi sikap responden mengenai penyakit kusta yang ditampilkan pada Gambar 2. Hasil analisis univariat responden didapatkan bahwa dari 19 responden yang memiliki sikap baik sebanyak 14 orang $(73,7 \%)$, dan sikap yang buruk sebanyak 5 orang $(26,3 \%)$.

Berdasarkan hasil kuisioner mengenai sikap terhadap kusta yang diisi oleh keluarga pasien, menunjukkan masih terdapat beberapa jawaban yang salah yang diuraikan pada Tabel 3.

Berdasarkan hasil wawancara dengan responden masih terdapat keluarga yang memiliki stigma negatif terhadap kusta yaitu kusta merupakan penyakit kutukan atausihir. Selain itu, sebagian responden tidak mengetahui cara penularan penyakit kusta. Oleh karena itu, penderita cenderung dikucilkan bahkan dipasung atau ditempatkan dirumah lain.

Berdasarkan hasil penelitian didapatkan diistribusi frekuensi tingkat kecacatan pada penderita kusta yang ditunjukkan pada Gambar 3. Hasil penelitian mendapatkan pasien dengan tingkat kecacatan 0 sebanyak 13 orang $(68,4 \%)$, dan penderita cacat sebanyak 6 orang $(31,6 \%)$. Analisis bivariat bertujuan untuk melihat adanya hubungan antara variabel bebas dangan variabel terikat. Berdasarkan hasil penelitian maka didapatkan hubungan pengetahuan keluarga dengan tingkat kecacatan penderitakusta yang ditampilkan pada Tabel 4. 


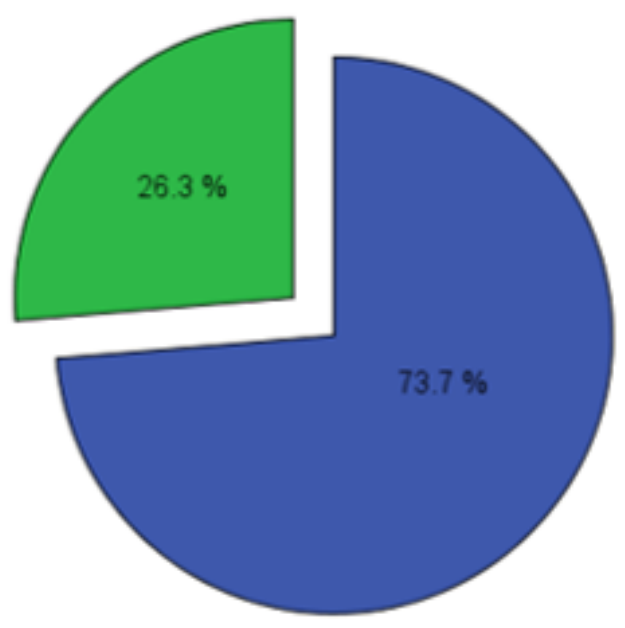

Buruk

Baik

Gambar 2. Distribusi sikap responden mengenai penyakit kusta.

Tabel 3. Rincian hasil kuisioner sikap keluarga.

\begin{tabular}{lcc}
\hline \multicolumn{1}{c}{ Pertanyaan } & Setuju & Tidak Setuju \\
\hline Penyakit kusta bukan penyakit kutukan & 16 & 3 \\
\hline Penyakit kusta adalah penyakit menular & 14 & 5 \\
\hline Penyakit kusta dapat sembuh setelah minum obat & 16 & 3 \\
\hline Penderita kusta harus minum obat sesuai anjuran petugas kesehatan & 14 & 5 \\
\hline Penyakit kusta dapat diobati disemua pelayanan kesehatan & 14 & 5 \\
\hline Setiap 2 bulan sekali penderita mengambil obat & 10 & 9 \\
\hline Penderita kusta bisa bergaul dengan masyarakat & 8 & 11 \\
\hline Keluarga boleh menyentuh penderita kusta & 15 & 4 \\
\hline Penyakit kusta adalah penyakit yang menakutkan & 8 & 11 \\
\hline MDT merupakan pengobatan paling baik bagi penderita kusta & 9 & 10 \\
\hline Keluarga mengawasi setiap penderita minum obat & 6 & 13 \\
\hline Penyakit kusta selalu menyebabkan luka & 9 & 10 \\
\hline
\end{tabular}

Tabel 4. Hubungan pengetahuan keluarga dengan tingkat kecacatan pasien kusta.

\begin{tabular}{|c|c|c|c|c|c|c|c|c|}
\hline \multirow[t]{3}{*}{ Pengetahuan } & \multicolumn{4}{|c|}{ Tingkat Kecacatan } & \multicolumn{2}{|c|}{ Total } & \multirow[t]{3}{*}{ OR } & \multirow[t]{3}{*}{$p$ value } \\
\hline & \multicolumn{2}{|c|}{ Tidak Cacat } & \multicolumn{2}{|c|}{ Cacat } & \multirow{2}{*}{$\mathrm{F}$} & \multirow{2}{*}{$\%$} & & \\
\hline & $\mathrm{F}$ & $\%$ & $\mathrm{~F}$ & $\%$ & & & & \\
\hline Baik & 11 & 91,7 & 1 & 8,3 & 12 & 100 & 8,146 & 0,010 \\
\hline Buruk & 2 & 28,6 & 5 & 83,0 & 7 & 100 & & \\
\hline Jumlah & 13 & 68,4 & 6 & 31,6 & 19 & 100 & & \\
\hline
\end{tabular}




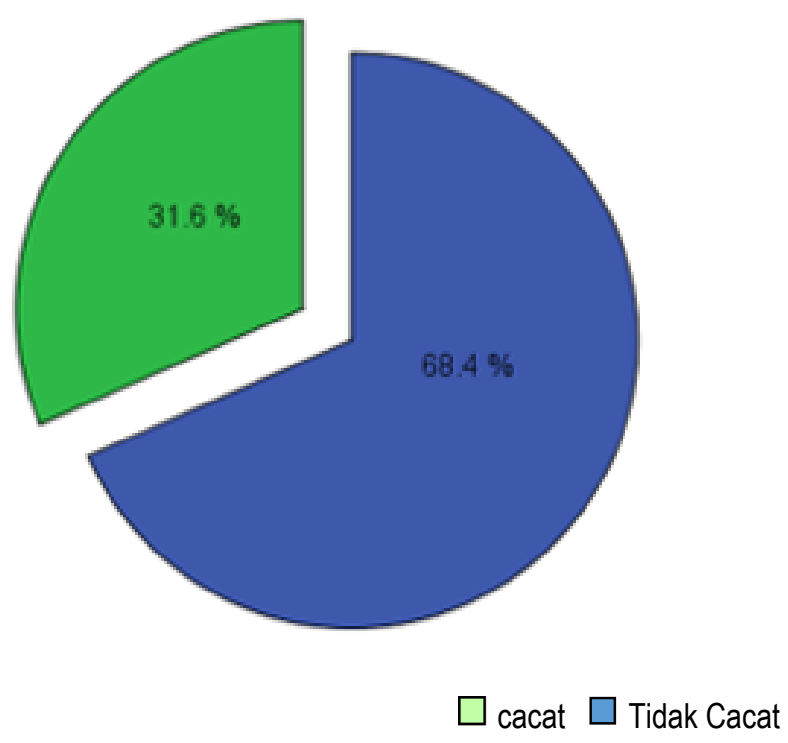

Gambar 3. Distribusi sampel menurut tingkat kecacatan.

Tabel 5. Hubungan sikap keluarga dengan tingkat kecacatan.

\begin{tabular}{|c|c|c|c|c|c|c|c|c|}
\hline \multirow[t]{3}{*}{ Sikap } & \multicolumn{4}{|c|}{ Tingkat Kecacatan } & \multicolumn{2}{|c|}{ Total } & \multirow[t]{3}{*}{ OR } & \multirow[t]{3}{*}{$p$ value } \\
\hline & \multicolumn{2}{|c|}{ Tidak Cacat } & \multicolumn{2}{|c|}{ Cacat } & \multirow[b]{2}{*}{$\mathrm{F}$} & \multirow[b]{2}{*}{$\%$} & & \\
\hline & $\mathrm{F}$ & $\%$ & $\mathrm{~F}$ & $\%$ & & & & \\
\hline Baik & 12 & 85,7 & 2 & 14,3 & 14 & 100 & 7,363 & 0,017 \\
\hline Buruk & 1 & 20,0 & 4 & 80,0 & 5 & 100 & & \\
\hline Jumlah & 13 & 68,4 & 6 & 31,6 & 19 & 100 & & \\
\hline
\end{tabular}

Berdasarkan Tabel 4, dapat dilihat bahwa dengan uji Chi square diperoleh $p$ value sebesar 0,01 , yang menunjukkan ada hubungan yang signifikan antara pengetahuan keluarga dengan tingkat kecacatan pada batas kesalahan (a) sebesar 5\%. Hasil analisis Odds Ratio (OR) adalah sebesar 8,146 yang berarti keluarga dengan pengetahuan kurang baik dapat meningkatkan risiko terjadinya kecacatan pada penderita kusta delapan kali lipat dibandingkan dengan keluarga yang memiliki pengetahuan baik. Pada Tabel 5, ditunjukkan bahwa $p$ value pada analisis Chi square sebesar 0,017. Hal ini menunjukkan ada hubungan yang bermakna antara sikap keluarga dengan tingkat kecacatan penderita kusta pada batas kesalahan 5\%. Nilai Odds Ratio (OR) sebesar 7,363 menunjukkan keluarga dengan sikap buruk berisiko tujuh kali lipat dibandingkan dengan keluarga dengan sikap baik.

\section{Pembahasan}

Pengetahuan responden ditentukan berdasarkan hasil wawancara dan kuesioner yang diisi langsung oleh responden. Pengetahuan dibagi menjadi 3 kategori yaitu pengetahuan baik (76-100\%), cukup (56$75 \%)$, dan kurang $(<56 \%) .{ }^{18}$ Pada penelitian ini, pengukuran ditentukan berdasarkan banyaknya jawaban benar dari 15 pertanyaan yang telah divalididasi dan dikelompokkan menjadi berpengetahuan baik dan kurang. Bagi responden yang memiliki pengetahuan cukup dikelompokkan 
ke dalam pengetahuan baik karena dianggap mengerti tentang penyakit kusta.

Pengetahuan merupakan salah satu dari dua variabel bebas pada penelitian ini. Penelitian ini mendapatkan sebanyak $63,2 \%$ responden memiliki pengetahuan dengan kategori baik, dan sebanyak $36,8 \%$ memiliki pengetahuan kurang. Secara statistik juga didapatkan hubungan yang bermakna antara pengetahuan dan tingkat kecacatan $(p=$ $0,010)$.

Keluarga merupakan salah satu faktor eksternal yang memberi pengaruh pada tingkat kecacatan penderita. Pada penelitian ini, pengetahuan keluarga terhadap penyakit kusta sebagian besar baik, dan sebagian yang memiliki keluarga berpengetahuan baik diketahui memiliki tingkat kecacatan nol. Hal ini sesuai dengan penelitian Sajidin (2015) dengan hasil yang signifikan antara peran keluarga dengan tingkat kecacatan pada penderita kusta. ${ }^{19}$

Pengetahuan yang cukup baik dapat mencegah kecacatan yang terjadi pada penderita kusta. Tidak semua pengetahuan yang baik dapat mencegah kecacatan, demikian sebaliknya. ${ }^{14}$ Hal ini karena beberapa faktor terlihat pada penelitian ini yaitu terdapat $8,3 \%$ yang berpengetahuan baik tetapi keluarganya menderita cacat. Berdasarkan wawancara, penyebab hal tersebut adalah keluarga mendapatkan informasi tentang penyakit kusta setelah penderita mengalami kecacatan.

Pada penelitian ini terdapat $28,6 \%$ responden yang berpengetahuan kurang tetapi keluarganya tidak cacat. Hasil wawancara dengan responden didapatkan bahwa awalnya responden belum mengerti tentang penyakit kusta yang diberikan oleh petugas kesehatan. Namun, setelah keluarga penderita mengetahui hal tersebut, mereka segera mengantarnya untuk berobat ke rumah sakit.

Sejalan dengan pendapat Friedman yang menyatakan bahwa keluarga dapat membuat keputusan tindakan kesehatan yang tepat bagi anggota keluarga yang sakit. ${ }^{10}$ Dengan demikian, jika pengetahuan keluarga cukup baik maka dapat mengurangi tingkat kecacatan secara dini dengan merawat pasien dengan baik. Apabila dalam keluarga masih terdapat stigma atau ketidaktahuan mengenai kusta, maka penderita kusta dapat mengalami perlakuan yang diskriminatif dan tidak mendapatkan pertolongan yang memadai. ${ }^{11} \mathrm{Hal}$ ini mengakibatkan penderita kusta tidak mendapatkan perawatan yang baik oleh keluarga yang merawat.

Menurut Azwar (2009) sikap dikelompokkan menjadi tiga kategori yaitu baiik (76-100\%), cukup (51-75\%), dan buruk $(<50 \%)$. $^{18}$ Pada penelitian ini sikap keluarga dikelompokkan menjadi baik dan buruk, untuk kategori cukup dimasukkan kedalam kelompok baik. Pengukuran ditentukan berdasarkan jumlah hasil pernyataan kuesioner dengan jawaban nilai terbesar adalah 4 dan paling rendah adalah 1 dari jawaban Sangat Setuju sampai Sangat tidak setuju dengan menggunakan skala Likert. ${ }^{21}$ Secara statistik terdapat hubungan yang bermakna antara sikap keluarga dengan tingkat kecacatan pada penderita kusta di RS. Dr. Saiful Anwar Malang $(p=0,017)$.

Penelitian ini mendapatkan bahwa sikap keluarga terhadap penyakit kusta sebagian besar memiliki sikap yang baik dan memiliki tingkat kecacatan nol atau tidak cacat. Hal ini sesuai dengan penelitian Sari di Padang Pariaman yang menyatakan terdapat hubungan yang bermakna antara sikap keluarga dengan tingkat kecacatan pada penderita kusta $(p=0,035) \cdot{ }^{15}$ Namun, ada beberapa faktor yang mengakibatkan kecacatan selain sikap. Hal ini terbukti dalam penelitian ini terdapat $14,3 \%$ yang memiliki sikap yang baik tetapi keluarganya menderita cacat. Menurut wawancara yang dilakukan pada semua responden diketahui 
bahwa beberapa responden mendapat informasi yang benar tentang kusta setelah terjadi kecacatan.

Responden yang memiliki sikap buruk tetapi keluarganya tidak cacat yaitu sebanyak 20\% dari total responden. Menurut wawancara dengan responden, masih terdapat kepercayaan bahwa kusta diakibatkan oleh kutukan dan masih terdapat perlakuan yang diskriminatif terhadap penderita kusta. Tetapi pada akhirnya penderita kusta mengetahui penyakitnya dan segera melakukan pengobatan.

Sikap negatif adalah kecenderungan untuk menjauhi, menghindari, membenci, tidak menyukai objek tertentu. ${ }^{22}$ Sikap negatif atau stigma keluarga atau masyarakat memiliki pengaruh yang besar terhadap psikososial penderita kusta. ${ }^{23}$ Keluarga yang memiliki sikap positif cenderung mendukung penderita kusta. Sikap positif ini bisa didapatkan dari penyuluhan kepada keluarga dan masyarakat sebagai bentuk pencegahan kecacatan atau sebaliknya, membuat cacat yang ada memburuk. Selain keluarga, masyarakat berperan dalam faktor budaya, masih terdapat persepsi yang salah tentang penyakit kusta yaitu menganggap kusta sebagai penyakit sihir dan harus dikucilkan. ${ }^{24}$

Keluarga sebagai pendukung bagi anggota keluarga yang sakit diharapkan dapat memberikan dukungan penuh dalam upaya perawatan penderita kusta. ${ }^{24} \mathrm{Hal}$ ini tampak dari hasil penelitian bahwa $85,7 \%$ keluarga dengan sikap baik, maka sebagian besar tidak cacat.

Tingkat kecacatan dikelompokkan mengacu pada kriteria World Health Organization yaitu grade 1 , grade 2 , dan grade 3.8,9 Tingkat kecacatan diukur dengan observasi langsung pada pasien penderita kusta dan beberapa dari rekam medis pasien di RS. Dr. Saiful Anwar dan dikelompokkan menjadi cacat (grade 1 dan grade 2) dan tidak cacat (grade 0).

Hasil penelitian ini menunjukkan pasien dengan tingkat kecacatan 0 atau tidak cacat sebanyak 13 orang, sedangkan pasien cacat sebanyak 6 orang. Penelitian ini hanya meneliti satu Rumah Sakit yang merupakan rumah sakit rujukan dari berbagai daerah di Jawa Timur. Oleh karena itu, kecacatan dapat diperoleh dari lamanya proses rujukan yang mengakibatkan keterlambatan diagnosis. Keterlambatan dalam penemuan kasus baru tersebut menyebabkan penderita kusta pada saat ditemukan telah berada dalam kondisi cacat yang permanen. ${ }^{25}$

\section{Kesimpulan}

Berdasarkan hasil penelitian terdapat hubungan yang bermakna antara pengetahuan keluarga dan sikap keluarga dengan tingkat kecacatan pada penderita kusta. Dari 19 penderita kusta terdapat $68,4 \%$ penderita kusta yang tidak cacat atau grade 0 dan $31,6 \%$ penderita yang mengalami kecacatan. Sebagian besar keluarga $(63,2 \%)$ memiliki pengetahuan baik, dan sebanyak $36,8 \%$ memiliki pengetahuan kurang. Sikap yang baik ditunjukkan oleh $73,7 \%$ keluarga, dan sikap buruk ditunjukkan oleh 26,3\% keluarga.

\section{Daftar Pustaka}

1. Widasmara D, Agusni I, Turchan A. Evaluation of Myelin Sheath Marker Krox-20 for Detection of Early Disability in Leprosy. Indian Journal leprosy. 2016; 88:105-110.

2. Kar HK and Kumar B. IAI Textbook of Leprosy. India: Jaypee Brothers Medical Publishers. 2010.

3. Amirudin MD, Hakim Z, Darwis E. Diagnosis Penyakit Kusta. Edisi ke-2. Jakarta: Balai Penerbit FKUI.2013. HIm. 12-31. 
4. Direktorat Jendral Pengendalian Penyakit dan Penyehatan lingkungan Kementerian Kesehatan RI. Pedoman Nasional Program Pengendalian Penyakit Kusta. Jakarta. 2012.

5. World Health Organization. Weekly Epidemiological Record. (Online). 2015.

http://www.who.int/lep/epidemiology/en I.Diakses 4 Januari 2017.

6. World Health Organization. Weekly Epidemioiogicai Record. 2012; 34(87): 317-328.

7. Dinas Kesehatan Kota Malang. Profil Kesehatan Kota Malang. Malang: Dinas Kesehatan.2014.

8. World Health Organization. Standard MDT Regimens. WHO Expert Committee on Leprosy.2012; 968:17.

9. World Health Organization. Monitoring Grade-2 Disability Rate and Applicability of Chemoprophylaxis in leprosy Control. Report of the Informal Consultation. 2019.

10. Friedman. Helping Families Cope with Mental Illness. USA: Harwood Academic Publisher. 2012.

11. Soedarjatmi, Tinuk I, Laksmono W. Faktor-Faktor yang Melatarbelakangi Persepsi Penderita terhadap Stigma Penyakit Kusta. Jurnal Promosi Keseharan Indonesia.2015;4(1):18-24

12. World Health Organization. Leprosy: Lessons to be Learnt in Overcoming Discrimination and Stigmatization. (Online). 2016. http://www.who.int/neglected_diseases/ news/leprosy lessons to be learnt/en I. Diakses 4 Januari 2017.

13. Van Brakel WH et al. Disability in People Affected by Leprosy: the Role of Impairment, Activity, Social Participation, Stigma and Discrimination. Global Health Action. 2012.
14. Susanto N. Faktor-Faktor yang Berhubungan dengan Tingkat Kecacatan Penderita Kusta di Kabupaten Sukoharjo. Tesis. Yogyakarta: Sekolah Pasca Sarjana Universitas Gadjah Mada. 2006.

15. Sari AN, Gustia R, Edison. Hubungan Pengetahuan dan Sikap Keluarga dengan Tingkat Kecacatan pada Penderita Kusta di Padang Pariaman Tahun 2013. Jurnal Kesehatan Andalas. 2015. 4(3):681-688.

16. World Health Organization. Global Leprosy Strategy 2016-2020. Monitoring and Evaluation Guide. (Online). 2016. http://apps.searo.who.int/PDS_DOCS/B 5305.pdf. Diakses 5 Januari 2017.

17. World Health Organization. Prevention of Disabilities in Patients with Leprosy: A Practical Guide / H. Srinivasan. (Online). 2015. http://www.who.int/iris/handle/10665/41 226. Diakses 6 Januari 2017.

18. Azwar. Sikap Manusia Teori dan Pengukurannya. Edisi ke-2. Yogyakarta: Pustaka Pelajar. 2009.

19. Sajidin M. Model Peran Keluarga dalam Upaya Mencegah Tingkat Kecacatan pada Penderita Kusta. Disertasi. Surabaya: Sekolah Pasca Sarjana Universitas Airlangga. 2015.

20. Patil A et al. Childhood Leprosy in India Over the Past Two Decades. International Journal leprosy. 2016; 82(2):93-99.

21. Notoatmodjo S. Metode Penelitian Kesehatan. Edisi revisi. Jakarta: Rineke Cipta. 2010.

22. Purwanto. Metodologi Penelitian Kuantitatif. Yogyakarta: Pustaka Belajar. 2012.

23. Majumder N. Socio-Economic and Health Status of Leprosy Affected Person: A Study in Jharkhand. Indian Journal Leprosy. 2015; 87(3):145-154. 
24. Lestoria JC and Abreu MAMM. Leprosy: Review of the Epidemioiogicai, Ciinical, and Etiopathogenic Aspects. An Bras Dermatol. 2015; 89(2):205-218.

25. Patil AA and Sherkhane MS. ClinicoEpidemioiogicai Study of Hansen's
Disease Patients Attending a Tertiary Care Centre in South India.International Journal of Community Medicine and Public Health. 2016; 3(11):3092-3095. 